\title{
Cephalosporin Antibiotic
}

National Cancer Institute

\section{Source}

National Cancer Institute. Cephalosporin Antibiotic. NCI Thesaurus. Code C357.

A synthetic or semi-synthetic beta-lactam antibiotic derived from Acremonium

(Cephalosporium) fungi with bactericidal activity. Cephalosporin antibiotics bind to and inactivate penicillin-binding proteins (PBPs) located on the inner membrane of the bacterial cell wall. Inactivation of PBPs interferes with the cross-linkage of peptidoglycan chains necessary for bacterial cell wall strength and rigidity. This interrupts bacterial cell wall synthesis and results in the weakening of the bacterial cell wall, eventually causing cell lysis. 